Published on Reviews in History (https://reviews.history.ac.uk)

\title{
Archbishop Pole
}

Review Number: 1642

Publish date: Thursday, 14 August, 2014

Author: John Edwards

ISBN: 9781409420576

Date of Publication: 2013

Price: $£ 70.00$

Pages: $314 \mathrm{pp}$.

Publisher: Farnham

Publisher url: http://www.ashgate.com/isbn/9781409420576

Place of Publication: Ashgate

Reviewer: Francis Young

John Edwards's new biography of Cardinal Reginald Pole, part of Ashgate's Archbishops of Canterbury Series, is a magnificent example of first-rate historical scholarship. Reginald Pole is no easy subject. He can seem like a man who lived several lives: the early years as a nobleman of royal blood serving Henry VIII; the young Cardinal intent on organising a crusade against England's heretic king; the controversial yet towering Catholic reformer who was so nearly elected Pope; and finally, the last Catholic Archbishop of Canterbury. To write a compelling narrative biography of such a man is a significant achievement in its own right. All current scholarship on Pole is inevitably underpinned by the work of the late Thomas F. Mayer on Pole's correspondence, and Mayer's biography Reginald Pole: Prince and Prophet (1) is a hard act to follow. Edwards manages to do so by shifting the focus away from Pole's writings and 'self-construction' and adopting the prosopographical approach that Mayer eschewed. Edwards's concentration on Pole's career as Archbishop (which occupies half the book) allows him to place Pole in the context of the latest scholarship on Marian England.

The first five chapters of Edwards's book deal with Pole's background and early career, his break with Henry over the divorce, and his role as a Catholic reformer in Italy. Chapter five deals with the various legations in the 1530s and 1540s that made it look as though he might be returning to England. The next four chapters deal with Pole's return to England, beginning with his appointment as legate a latere with the power to reconcile England to the Holy See, and moving to his role as Archbishop of Canterbury and the heresy proceedings started against him in Rome by his one-time friend Gianpietro Carafa (Pope Paul IV). Pole's death and subsequent reputation are also covered, and Edwards helpfully includes an appendix with translated extracts of some of Pole's most important works. This is a book that will doubtless come to be regarded as the authoritative introduction to Pole, and whilst Pole's status as a European Catholic reformer is now recognised, Edwards's book shines a much-needed light on the details of Pole's achievement in England.

Edwards's decision to deal in some details with Pole's family and his status as a Yorkist princeling is important for placing in context Pole's early career as a diplomat, his murky role in negotiations for Henry VIII's divorce, and his attack on Henry's religious policy, De unitate. Edwards makes a convincing case that Pole acted in support of Henry's divorce, in spite of Pole's subsequent efforts to re-write an aspect of his 
personal history that subsequently became embarrassing (pp. 22-9). Throughout his life, however, Pole was committed to the unity of Christendom, and his support for the divorce was consistent with that aim; only after it became clear that Henry had no intention of pursuing the divorce through 'Catholic' means did Pole break with the king. Henry expected loyalty from someone 'of the blood royal', and therefore Pole's 'rupture' with Henry was especially tumultuous. As Edwards acknowledges, the complexity of Pole's life, compounded by his verbose prose, is a challenge to the historian (p. $\mathrm{x}$ ). However, he makes a compelling case for Pole's importance as a man who combined ideas that were later regarded as incompatible, especially his commitment to Catholic Christendom and his belief in justification by faith (p. xi). A study of Pole's life and thought highlights the multiple and contested meanings of 'reform' in the 16th century, and Pole defies the imposition of glib religious labels.

Although the precise nature of the soul-searching that led Pole to turn against the divorce in 1531 is irrecoverable, Edwards does a fine job of delineating the subtle shifts in Pole's position. Pole's concern in 1531 was with Henry's honour (p. 41); Pole was expecting a General Council, and he considered it 'dishonourable' for Henry and the English nation if English bishops were not involved (p. 63). Henry was the victim of 'evil advisors' (p. 70). Even after the executions of Fisher and More, Pole adopted the tone of a 'stern father confessor' (p. 51) or styled himself as a prophetic witness against Henry's folly (p. 53). Only later did Pole openly denounce Henry as a greater threat to Christendom than the Turks, but in De unitate he put forward the dangerous idea, that would haunt English Catholics long after his death, that the people could choose to depose their ruler (p. 54). Pole's writings against Henry, and his elevation to the cardinalate, would lead eventually to the execution of his mother, Margaret Pole, and the near destruction of his family.

The Pilgrimage of Grace led the Pope to send the new cardinal on a legation to Paris, with the intention of organising a Catholic invasion of England, but Edwards demonstrates that Pole's capture was frustrated by Henry's ambassador in Paris, Stephen Gardiner, as well as hampered by Henry's own indecision (pp. 66-7). Pole was outraged by the supposed burning of the bones of St Thomas Becket (p. 77), and began negotiating in earnest with Charles V for an invasion of England. Henry, in turn, sent a series of assassins after him.

However, Pope Paul III was not prepared to let Pole's administrative and theological talents go to waste, and in 1541 he was appointed legate to the Patrimony of Peter, which put him in charge of the government of the Papal States in central Italy (p. 91). During this time Pole became the centre of a reformist theological circle at Viterbo, which included some members, such as Piero Martire Vermigli, who would go on to identify themselves with the Protestant Reformation (p. 92). Pole's Viterbo circle would be persecuted by Carafa in the $1550 \mathrm{~s}$.

The climax of Pole's Italian career came in January 1546, when Angelo Massarelli read Pole's sermon to the opening session of the Council of Trent. Edwards traces the evolution of this sermon from Pole's De concilio and draws attention to his careful navigation between papalist and conciliarist positions. Distinctive to Pole, however, was his insistence on the 'infusion of the Holy Spirit' as necessary for both pope and council, and on the priority of faith for salvation (pp. 106-7). Yet Pole's 'charismatic' conception of authority and 'evangelical' soteriology would be rejected, and in June 1546 Pole himself left Trent. Although Edwards declines to speculate on Pole's motives for leaving, he notes the view expressed by many in the 1550s that Pole was avoiding a vote on the decree on justification (p. 108).

Edwards argues that it was not until Edward VI's government threatened the mass by bringing in the English Prayer Book that Pole became determined to return to England (p. 111). However, events were conspiring to keep Pole in Italy for the time being; he consistently polled the highest number of votes in the conclave of 1549 and, finally, when he was just two votes off an overall majority, Alessandro Farnese suggested that Pole should be declared Pope by 'adoration' of the cardinals. It seems likely that this would have happened, had not Carafa accused Pole of heresy (p. 117). Even after this, Pole continued to do well in the ballots, and even emerged as a front-runner in the conclave of 1555, but Pope Reginald was not to be. Pole's greatest contribution to the papacy, in the end, was his treatise De summo pontifice, in which he argued for a deeply spiritual, humble pope, different in degree but not in kind from the bishops he led, who might be deposed by a General Council (pp. 118-19). As Pole had argued in De unitate, the pope's leadership of the church was 
'hierarchical', but not 'monarchical' (p. 52). Edwards's description of Pole's views on the papacy has contemporary resonances with Pope Francis's efforts to reorient the papacy towards a less monarchical model.

Edwards meticulously clarifies the nature of the legatine powers that were conferred on Pole at Mary's accession, and how these related to the evolving legal position in England. Pole was, in effect, virtually the equal of the Pope himself in terms of the powers bestowed on him (p. 122). However, because Mary insisted on Parliament approving the reconciliation of England with the Holy See, Pole was left in limbo in the Low Countries, and when he did finally enter England, for procedural reasons he was received as a Papal ambassador, not as Legate. Canon law was, effectively, moving faster than the law of England, and it took time for the two to fall into step. It was only on the day of England's formal reconciliation with the Holy See, 30 November 1554, that Pole was legally able to exercise his legatine powers. Edwards's account draws attention to the gradual, even cautious nature of the Marian restoration which can sometimes be obscured in accounts of the period.

Edwards makes an important contribution to the assessment of Pole as archbishop, confronting the Marian burnings and noting that 'Pole could write lyrically of the sufferings of Fisher and More, while apparently blocking any feeling of compassion for the reformers who were burnt to death under his authority' (p. 154). He does not attempt to excuse Pole, noting that although Pole delegated heresy trials for much of his archiepiscopate, he eventually acted directly to condemn heretics in 1558, possibly in order to strengthen his own orthodox credentials when he was under investigation for heresy in Rome (p. 224). At the same time, Pole understood that pastoral sensitivity was needed to bring England back to the faith, and he 'regarded heretics as errant children' rather than irredeemable sinners (p. 163). For example, Pole did not insist on the exhumation of the remains of Protestants buried in churches for sound practical and pastoral reasons ( $\mathrm{p}$. 136). Edwards maintains that Pole was a more competent reformer of the English church than Mayer suggested (p. 169), and did not bypass the Council of Trent. His suppression of 'church ales' in the naves of churches, amongst other things, showed that he had imbibed some of the 'Catholic puritanism' of Carafa and others (p. 173).

Challenging traditional views of Pole as a legalistic conservative, Edwards shows that Pole supported preaching (pp. 174-5), diocesan seminaries (p. 177) and reform of the universities (pp. 179-88), as well as being heavily involved in the restoration of religious houses. He tackles Pole's unwillingness to admit the Jesuits to England, showing that this was due to political sensitivities surrounding the Jesuits in Italy (connected with Carafa's Theatines) rather than personal hostility on Pole's part (pp. 196-200). Edwards gives a detailed account of the progress of Carafa's witch-hunt against Pole, after his election as Pope Paul IV, and argues that it resulted in a reorientation of England's relationship with the papacy. When Pole was summoned to Rome by the Inquisition in the summer of 1557, Mary refused to let her subject be tried anywhere except in England, and 'From then on, she behaved as Queen of England first, and a Catholic ruler second' (p. 211). Mary's fierce support for Pole, who was stripped of all his legatine powers but continued to act under his metropolitical and Mary's royal authority, raises the intriguing question of whether, if Mary had lived longer, the Marian church might have reverted to some form of Henrician 'national Catholicism' (p. 212).

The final chapter of Edwards's book deals with Pole's legacy, including some interesting counterfactual speculation on who might have succeeded Pole as archbishop if Elizabeth had decided to keep England a Catholic country (pp. 257-8). Mary and Pole's move away from the papacy in 1558, so well recounted here by Edwards, explains why some contemporaries thought that Elizabeth might plump for Catholicism. On the other hand, Carafa's alienation of Mary and Pole hardly made it likely that Elizabeth would seek reconciliation with such a pope. Nevertheless, this book provides a fresh perspective on the intriguing months of uncertainty that followed the deaths of Mary and Pole and preceded the Elizabethan religious settlement.

Although this is not intended as a criticism of the book (every biography must draw its limits), I should have 
liked to find a deeper exploration of Pole's long-lasting popularity and influence in the English Catholic community in the final chapter. In the late 16th and early 17th centuries, the Pole family was active in support of the secular clergy, including the Appellants, against the Jesuits, making even more intriguing Edwards's suggestion that in his St Andrew's Day sermon of 1557, Pole 'was inviting "the great and the good" of Marian England to join him in securing the future of English Catholicism with or without the help of the pope' (p. 218). It is interesting to speculate on the extent to which Reginald Pole was the father of the 'dissenting tradition' within English Catholicism that would later spawn the Appellants, Blackloists and Cisalpinists, and one direction for further study could be an analysis of the use of Pole's works and ideas by later Catholic authors.

Edwards's biography is without doubt the best introduction to Reginald Pole now available. The Pole who emerges from this book is a genuinely holy (or at least spiritual) man, the greatest pope there never was, a towering figure of Reformation history in England and Europe, and a victim of Carafa's narrowing of the Catholic mind.

\section{Notes}

1. Thomas F. Mayer, Reginald Pole: Prince and Prophet (Cambridge, 2000).Back to (1)

Source URL:https://reviews.history.ac.uk/review/1642

\section{Links}

[1] https://reviews.history.ac.uk/item/106780 